\title{
純 $\mathrm{Al}$ および $\mathrm{Al}-\mathrm{Cu}$ 単結晶の応力腐食割れと (100) faceting 溶解*
}

\author{
昆謙造**, 久 松 敬 弘*** \\ **一関工業高等専門学校 ***東京大学工学部金属材料学科
}

\author{
Stress Corrosion Cracking and (100) Faceting Dissolution \\ of Pure Al and Al-Cu Single Crystals*
}

\author{
Kenzo Kon** and Yoshihiro Hisamatsu*** \\ **Ichinoseki Technical College \\ ***Department of Metallurgy and Materials Science, Faculty of Engineering, University of Tokyo
}

The characteristics of stress corrosion cracking (SCC) of pure $\mathrm{Al}$ and homogenized $\mathrm{Al}-\mathrm{Cu}$ single crystals were investigated with reference to crack morphology and faceting dissolution at various potentials in $1 \mathrm{~mol} / \mathrm{kg}-\mathrm{NaCl}$ solution, and then an electrochemical role of $\mathrm{NaCl}+\mathrm{H}_{2} \mathrm{O}_{2}$ solution which has been used as a SCC testing solution was examined in connection with pitting potential. Fracture time in $1 \mathrm{~mol} / \mathrm{kg}-\mathrm{NaCl}$ solution decreased exponentially with an increase of potential above the pitting potential $\left(\mathrm{V}_{\mathrm{c}}{ }^{\prime}\right)$ determined without stressing. Cracks are classified into the following three types according to applied potentials: well-type cracks which appear near $\mathrm{V}_{\mathrm{c}}$ ', similar cracks which issue from bottoms of pits with increase of potential and only pits which develope above $-0.40 \mathrm{~V}$ (vs. SCE). Cracks always grow due to (100) faceting dissolution. As growth rates of pits become larger than the rate of (100) faceting dissolution above $-0.40 \mathrm{~V}$, ductile fracture occurs by reduction of area due to pitting. When potentiostated, pure $\mathrm{Al}$ also suffers from $\mathrm{SCC}$ similar to $\mathrm{Al}-\mathrm{Cu}$ alloys at potentials near $\mathrm{V}_{\mathrm{c}}{ }^{\prime}$, but the susceptible potential range is narrow. The critical potential of SCC seems to correspond to the pitting potential under straining $\left(\mathrm{V}_{\mathrm{c} \sigma}{ }^{\prime}\right)$. Spontaneous corrosion potential in $1 \mathrm{~mol} / \mathrm{kg}-\mathrm{NaCl}+0.09 \mathrm{~mol} / \mathrm{kg}-\mathrm{H}_{2} \mathrm{O}_{2}$ solution is higher than $\mathrm{V}_{\mathrm{c} \sigma}{ }^{\prime}$ for several minutes, and decreases slowly with time to a constant value below $\mathrm{V}_{\mathrm{c}} \sigma^{\prime}$. This constant corrosion potential value is higher than the protection potential for $\mathrm{Al}-\mathrm{Cu}$ alloys and lower than that for pure Al. Therefore, the cracks of Al-Cu alloys keep growing due to (100) faceting dissolution and those of pure Al stops growing due to pit repassivation.

\section{1. まえがき}

ステンレス鋼や $\mathrm{A} 1$ 合金では不働態電位域が存在する が, $\mathrm{Cl}^{-}$存在下である電位を越えると，孔食を起こすよ うになる。これら合金の応力腐食割れ (SCC) 感受性域 の 1 つが孔食電位近傍にある場合が多いので，両者の間 には重要な関係があるものと考えられる。たとえば 304 鋼の高温・高濃度 $\mathrm{NaCl}$ 溶液拈よび比較的低濃度の $\mathrm{Cl}^{-}$ を含む高温・高圧水中の割れが食孔を起点として発生す

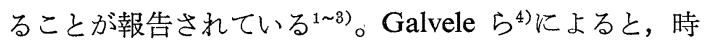

* 1977 年 5 月, 本会 '77 春期学術講演大会（於東 京）で発表

** 票021 一関市萩荘字高梨 (Hagisho Takanashi, Ichinoseki 021, Japan)

*** T113 東京都文京区本郷 7-3-1 7-3-1 Hongo, Bunkyo-ku, Tokyo 113, Japan)

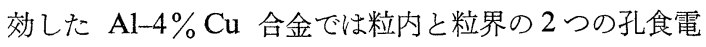
位が観察され，粒内孔食電位を越えると，粒内にtunnel 状の腐食が認められると述べている。杉本ら5゙ も同じ合 金系について同様の結果を得，さらに SCC との関係を 検討している。

$\mathrm{Al}$ 合金の粒内割れに関する研究は少ないが，Scully帛 は時効した $\mathrm{Al}-\mathrm{Zn}-\mathrm{Mg}$ 合金で一部に辟開による粒内破 面を，小島ら7)同じ合金系の単結晶の定ひずみ速度 SCC 試験で粒内割れを観察している。

粒内割れの結晶面についても 2,3 の報告がある ${ }^{8 \sim 10)}$ 。 たと壳ば Stubbington ${ }^{11)}$ は $\mathrm{Al}-\mathrm{Zn}-\mathrm{Mg}$ 合金の $\mathrm{NaCl}$ 溶 液中に打ける腐食疲労破面には応力成分によって 2 種類 の striation をもつ $\{100\}$ の幦開破壊を観察している。 このような $\{100\}$ での䢃開は $\mathrm{Al}$ の液体金属脆化で広く 
認められている12,13)。

$\mathrm{Al}$ 合金の $\mathrm{NaCl}$ 溶液中に拉将る食孔は全体として不 規則な形状をとる場合が多いが，初期の成長過程では結 晶粒によって異なった幾何学的形状をもつ小さな穴が特 定の方向に faceting 溶解をしていることが見出されて

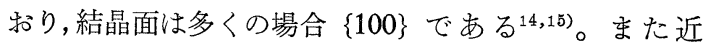
年, このような faceting 溶解が SCC や腐食疲労など で重要な役割をしていることが明らかになりつつあ る $^{16,17)}$ 。

本研究では固溶体化した $\mathrm{Al}-\mathrm{Cu}$ 単結晶について $\mathrm{NaCl}$ 溶液中, 定電位下で SCC 試験を行い, 割れの形態と電 位の関係, faceting 溶解の役割, さらに $\mathrm{Al}$ 合金の割れ 試験液として使用されている $\mathrm{NaCl}+\mathrm{H}_{2} \mathrm{O}_{2}$ 溶液の電気 化学的意味などを孔食電位に注目しながら検討した。ま た純 $\mathrm{Al}$ のSCCについても若干の検討を加えた。

\section{2. 実験方法}

\section{1 単結晶の作成}

純 $\mathrm{Al}$ と $\mathrm{Al}-30 \% \mathrm{Cu}$ 合金を用いて高純度黒鉛るつぼ 中で $\mathrm{Al}-1 \% \mathrm{Cu}$ 打よび $\mathrm{Al}-4 \% \mathrm{Cu}$ 合金を大気溶解し, 鍛造, 圧延して厚さ $2.2 \mathrm{~mm}$ の板とした。これから幅 $20 \mathrm{~mm}$, 全長 $100 \mathrm{~mm}$ を切り出し, $30 \mathrm{~mm} \phi$ のタンマン 管に入れて, アルミナ微粉で突き固めた後, 融点直上に 加熱した温度勾配を有する炉中を $3 \mathrm{~cm} / \mathrm{h}$ の速度で降下 させることにより単結晶を作成した。

\section{2 結晶方位の測定}

方位の測定は次のようにして行った。すなわち表面を 電解研磨後, $\mathrm{NaF}-\mathrm{HNO}_{3}-\mathrm{HCl}$ 系溶液中で, ポテンシ オスタットにより 0.1 V (vS. SCE) の定電位に設定して 数分間エッチングを行い，(100)によって囲まれた 30〜 $40 \mu \mathrm{m}$ のマイクロピットを作り，傾角顕微鏡を用い て構成面の角度を測定した。いくつかの試料については $\mathrm{X}$ 一線透過ラウエ法を同時に適用して, 両者が数度以内 で一致することを確かめた。

\section{3 試 験 片}

上記の単結晶板を $540^{\circ} \mathrm{C} \times 2 \mathrm{~h}$ 溶体化処理後水焼入れ し，表面で (100) trace と引張軸とのなす角が $60^{\circ} \sim 80^{\circ}$ になるように幅 $5 \mathrm{~mm}$ に超音波加工機で切断した。試 験片はすべてェメリ一紙で研磨後, $50^{\circ} \mathrm{C}$ の $\mathrm{NaOH}$ 溶 液中で表面層を除去し，次いで表面に付着した腐食生成 物を除去するために硝酸一メタノール溶液中に浸漬した。 また分極曲線を測定するための試験片としては, 表面が (100) であるものを $1 \mathrm{~cm} \times 1 \mathrm{~cm}$ に切断し, 同様の処理 をしたものを用いた。

\section{4 試 験 液}

試験液としては $1 \mathrm{~mol} / \mathrm{kg}-\mathrm{NaCl}$ および $1 \mathrm{~mol} / \mathrm{kg}$ $\mathrm{NaCl}+0.09 \mathrm{~mol} / \mathrm{kg}-\mathrm{H}_{2} \mathrm{O}_{2}$ 溶液を脱気せずに用いた。

\subsection{SCC 試験}

試験片を軟鋼製チャックにはさみ, 中心部 $2 \mathrm{~cm}$ を露 出し, 他の部分はビニコートで被覆した。試験容器は容 量 $300 \mathrm{~m} l$ のアクリル製のものを，対極はコイル状にし た白金線を用いた。応力は 5:1 の槓桿式の引張試験機に より付加し, 付加応力 $\sigma_{\mathrm{a}}=1.5 \sigma_{\mathrm{y}}\left(\sigma_{\mathrm{y}}\right.$ : 降伏応力, 純 $\mathrm{Al}$ で $\sigma_{\mathrm{y}} \doteqdot 6.86 \mathrm{MPa}, \mathrm{Al}-1 \% \mathrm{Cu}$ で $\sigma_{\mathrm{y}} \doteqdot 9.8 \mathrm{MPa}, \mathrm{Al}-4 \% \mathrm{Cu}$ で $\left.\sigma_{\text {у }} \doteqdot 24.5 \mathrm{MPa}\right)$ とした。

\section{3. 実験結果および考察}

\section{1 アノード分極曲線}

$1 \mathrm{~mol} / \mathrm{kg}-\mathrm{NaCl}$ 溶液中, $0.125 \mathrm{~V} / \mathrm{min}$ で最初アノード 方向に, 次いで電流密度が $60 \mathrm{~A} / \mathrm{m}^{2}$ からカソード方向 に sweep したときの無応力下に执ける分極曲線を Fig. 1 に示した。これから得られた孔食電位 $\left(\mathrm{V}_{\mathrm{c}}{ }^{\prime}\right)$ および保護 電位 $\left(\mathrm{E}_{\mathrm{R}}\right)$ を Table 1 にまとめて示した。 $\mathrm{V}_{\mathbf{c}}{ }^{\prime}, \mathrm{E}_{\mathrm{R}}$ とも に $\mathrm{Cu}$ 濃度が増すにつれて貴方向に移行する。この傾向 は従来の測定結果と一致する5)。

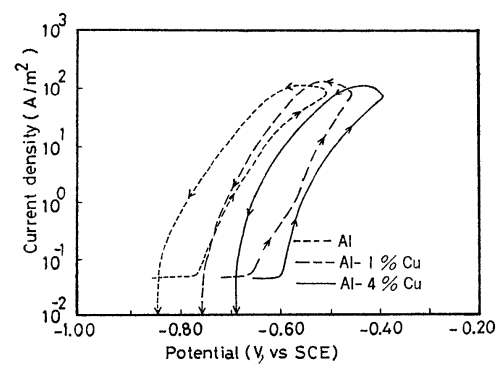

Fig. 1. Anodic polarization curves under no stress in naturally aerated $1 \mathrm{~mol} / \mathrm{kg}-\mathrm{NaCl}$ solution.

Table 1. Pitting potential $\left(\mathrm{V}_{\mathrm{c}}{ }^{\prime}\right)$ and protection potential $\left(\mathrm{E}_{\mathrm{R}}{ }^{\prime}\right)$ of pure $\mathrm{Al}$ and $\mathrm{Al}-\mathrm{Cu}$ alloys obtained from Fig. 1 (V,vs SCE).

\begin{tabular}{c|c|c|c}
\hline Potential & $\mathrm{Al}$ & $\mathrm{Al}-1 \% \mathrm{Cu}$ & $\mathrm{Al}-4 \% \mathrm{Cu}$ \\
\hline $\mathrm{V}_{\mathrm{C}}^{\prime}$ & -0.77 & -0.67 & -0.59 \\
\hline $\mathrm{E}_{\mathrm{R}}$ & -0.85 & -0.76 & -0.69 \\
\hline
\end{tabular}

\section{2 定電位下での SCC}

$\mathrm{Al}-1 \% \mathrm{Cu}$ 抽よび $\mathrm{Al}-4 \% \mathrm{Cu}$ 単結晶の $1 \mathrm{~mol} / \mathrm{kg}-\mathrm{NaCl}$ 溶液中での破壊時間 $\left(\mathrm{t}_{\mathrm{f}}\right)$ と電位 $(\mathrm{E})$ との関係を Fig. 2 に示した。いずれの合金でも $V_{c}{ }^{\prime}$ 以上では $t_{\mathrm{f}}$ は $\mathrm{E}$ の上 昇とともにほぼ指数関数的に減少した。また同じ Eで比 較すると， $\mathrm{Al}-1 \% \mathrm{Cu}$ の方が $\mathrm{Al}-4 \% \mathrm{Cu}$ より破壊しにく い。Fig. 3 はすでに報告した $\mathrm{NaCl}$ 溶液中における $\mathrm{Al}$ $\mathrm{Cu}$ 単結晶の衝撃変形後の電流密度の減衰を図式的に示 したものである18)。すなわち $\mathrm{E}<\mathrm{V}_{\mathrm{c}}{ }^{1}$ のときには変形 


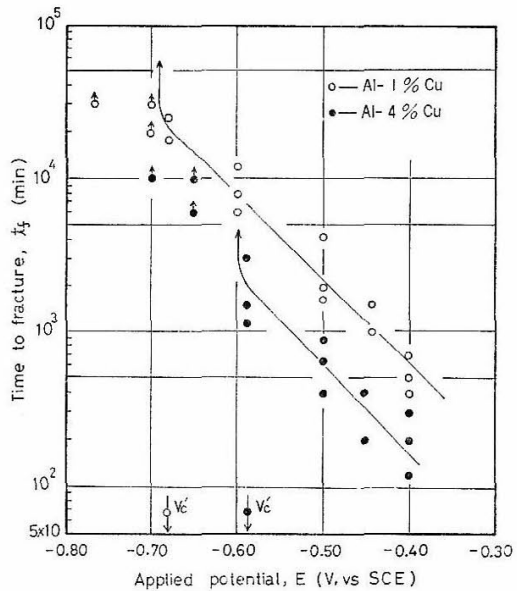

Fig. 2. Effect of applied potential on the time to fracture of $\mathrm{Al}-\mathrm{Cu}$ alloys in $1 \mathrm{~mol} / \mathrm{kg}$ $\mathrm{NaCl}$ solution.

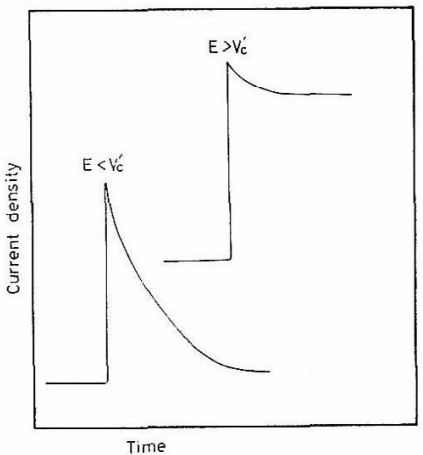

Fig. 3. Schematic representation of current density-time curves after impact deformation in $\mathrm{NaCl}$ solution.

後，電流は急激に減少するが， $\mathrm{E}>\mathrm{V}_{0}{ }^{\prime}$ になると電流の

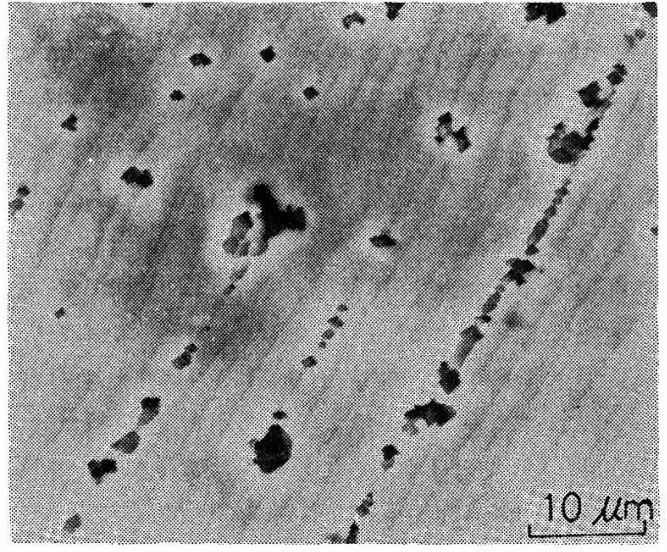

Fig. 4. (100) faceting dissolution along slip steps in the surface of specimen deformed at $-0.58 \mathrm{~V}$ in $1 \mathrm{~mol} / \mathrm{kg}-\mathrm{NaCl}$ solution.

減衣はゆるやかで，大きな電流が保持される。このこと 至 SCC 上関連させて考えると，前者で喫れ先端で新 生すべり面が露出してむ活性点の数が少なく，す文やか に再不働熊化してしまうが，後者では活性点の数も多 く，旮れらが溶解し続けるためと考兄られる。Fig. 4 は $\mathrm{V}_{\mathrm{c}}{ }^{\prime}$ 上りわずか高い $\mathrm{E}=-0.58 \mathrm{~V}$ で衝撃変形したと きの試料表面の様子を示したもので，すべりステップに 沿って優先的な腐食が起こって㧊り，しかもその形状か ら (100) faceting 溶解をしていることがわかる。しかし このようなずべりステッブに沿った方位性ピットの生成 は程度の美ことあれ， $V_{\mathrm{c}}{ }^{\prime}$ に近い不㗢態電位域でも観察 される年。

\section{3 電位による割れ形態の変化}

$\mathrm{Al}-4 \% \mathrm{Cu}$ 単結唱について, $\mathrm{E}=-0.58,-0.50$ 拈上 び $-0.45 \mathrm{~V}$ の各電位で剨れの試験を行い, 試験扸を途 中で取り出して，断面を観察した結果をFig. 5 に示し

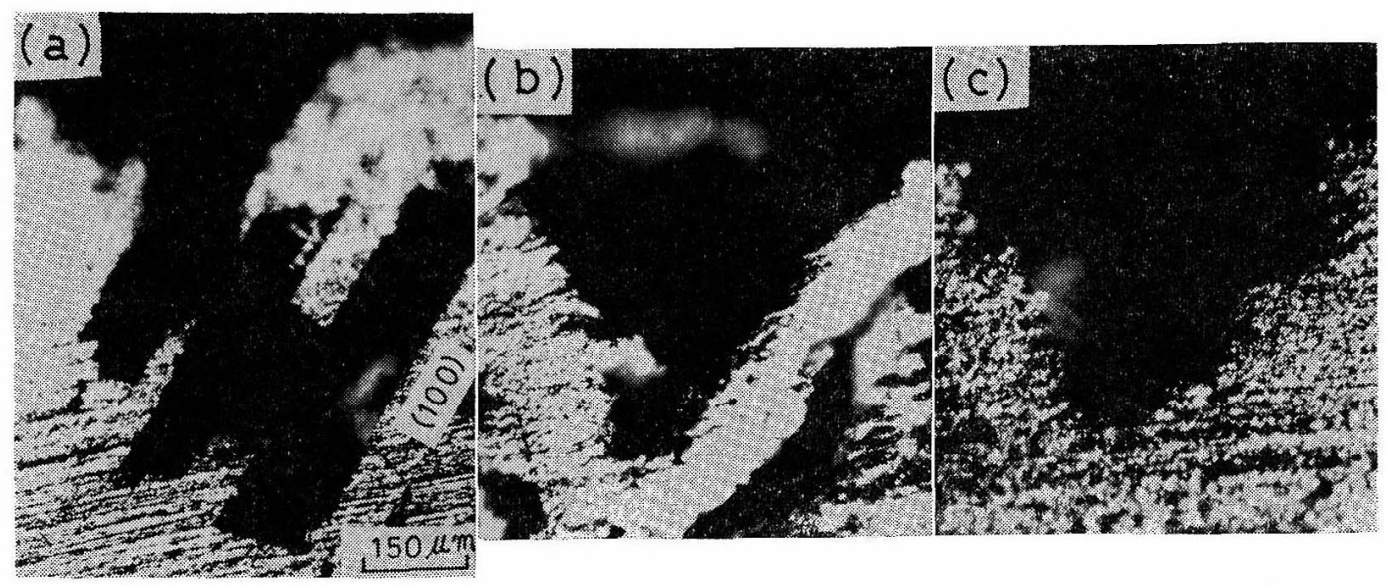

Fig. 5. Change of crack morphology of $\mathrm{A}-4 \% \mathrm{Cu}$ alloy with applied potential in $1 \mathrm{~mol} / \mathrm{kg}-$ $\mathrm{NaCl}$ solution. (a): $-0.58 \mathrm{~V}$, (b): $-0.52 \mathrm{~V}$, (c): $-0.45 \mathrm{~V}$. 
た。 $\mathrm{E}=-0.58 \mathrm{~V}$ では (100) faceting 溶解によって進行 した井戸型の割れのみしか認められないが, $\mathrm{E}=-0.52 \mathrm{~V}$ では食孔底に同樣の割れが，さらに電位が高い $\mathrm{E}=-$ $0.45 \mathrm{~V}$ では食孔のみしか認められなくなる。図には示 さなかったが， $V_{c}^{\prime}$ に近い不働態電位域でも，Fig. 5 (a) と同じような井戸型の割れが観察された。Fig. 6 は $1 \mathrm{~mol} / \mathrm{kg}-\mathrm{NaCl}$ 溶液中，無応力下と $12 \% / \mathrm{min}$ の定ひ ずみ速度で变形させながら孔食電位を測定したものであ る。変形下に括ける孔食電位 $\left(\mathrm{V}_{\mathrm{c} \sigma^{\prime}}\right)$ は，いずれの合金で も $\mathrm{V}_{\mathrm{e}}^{\prime}$ に比べて卑な值を示す。この攧向は純 $\mathrm{Al}$ で大き く, $\mathrm{Al}-4 \% \mathrm{Cu}$ では小さい。このことは電位がたと壳 $\mathrm{V}_{\mathrm{c}}^{\prime}$ 以下でも，応力が付加されている場合には， $\mathrm{V}_{\mathrm{c} \sigma}$ 'を越光 ている可能性があることを示している。

Staehle ${ }^{19)}$ は SCC を生でる電位域が $\mathrm{V}_{\mathrm{c}}{ }^{\prime}$ 上りわずか に卑な電位にあることをオーステナイトステンレス鎆に ついて示している。Fig. 7 は食孔の幅の広がり速度（大 よ气食孔の成長速度と考方られる）括よび割れの成長速 度と電位との関係を $V_{\mathrm{e}}{ }^{\prime}$ 以上について調べたものであ る。割行成長速度は $V_{\mathrm{c}}{ }^{\prime}$ 以上では指数関数的に增加卞

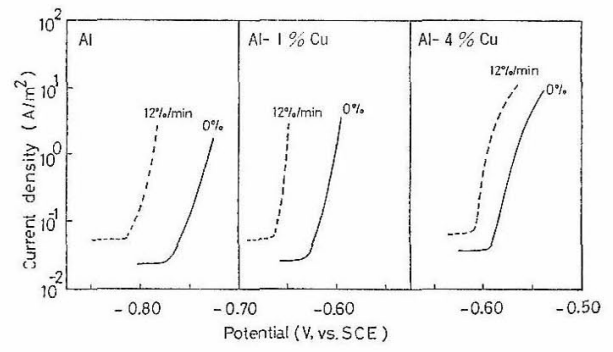

Fig. 6. Anodic polarization curves under straining and no straining in $1 \mathrm{~mol} / \mathrm{kg}-\mathrm{NaCl}$ solution.

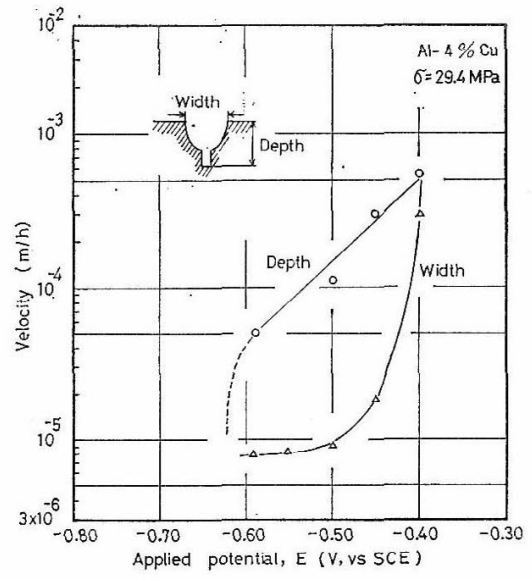

Fig. 7. Effect of applied potential on the growth rates of pit and crack in $1 \mathrm{~mol} / \mathrm{kg}-\mathrm{NaCl}$ solution.
る。一方，食孔の成長速度は $\mathrm{V}_{\mathrm{c}}{ }^{\prime}$ 付近では小さいが， あ る電位から急激炕大きくなり，-0.40 V 付近で両者の 速度は等しくなる。Fig. 8 は井戸型の溶解をしていると きの割れ先端を観察したもので，(100) faceting 溶解を 示す方位性ピットと，一部にすべり線が観察される。 Fig. 9 浽破面（井戸型）に作った方位性ピットとX-線 ラウエ像を示した。それぞれ破面が (100) であることを

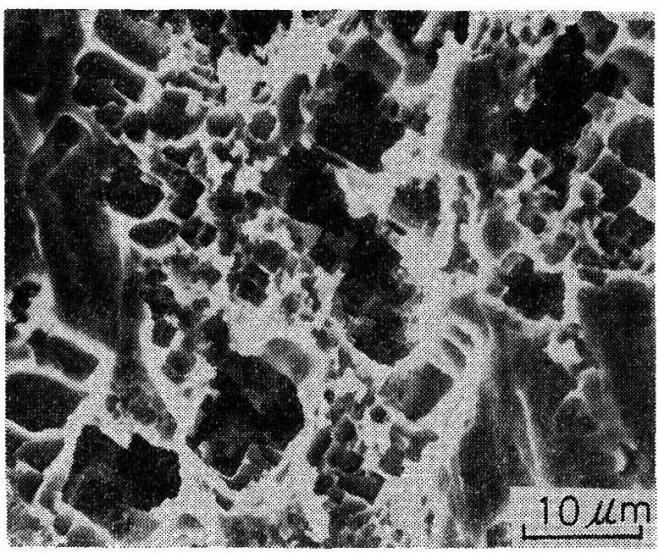

Fig. 8. (100) faceting dissolution at a crack tip of $\mathrm{Al}-4 \% \mathrm{Cu}$ alloy at $-0.58 \mathrm{~V}$ in $1 \mathrm{~mol} /$ $\mathrm{kg}-\mathrm{NaCl}$ solution.
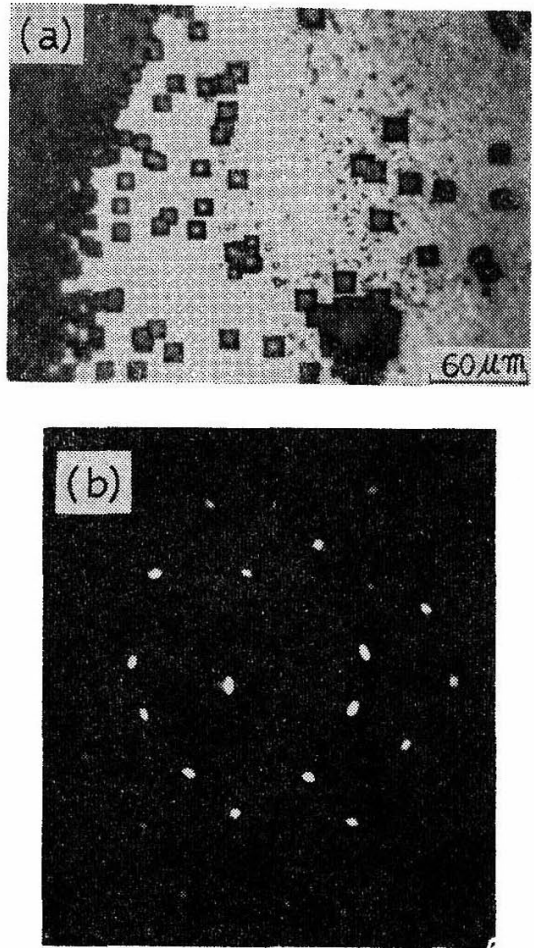

Fig. 9. Etch-pits (a) and X-ray Laue pattern (b) on a fracture surface, which show that the fracture surface is $(100)$ 


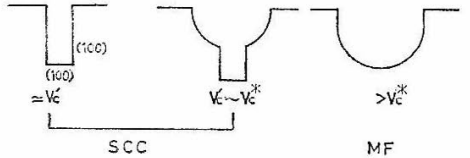

Fig. 10. Schematic representation of crack morphology with applied potential.

示す正方形の方位性ビットと典型的な (100) 回折パター ンをを示す。このことは割れが (100)を residual plane とする faceting 溶解によって進むことを示している。 Fig. 7 で食孔の成長速度と割れの成長速度が等しくなる 電位を $V_{\mathrm{o}}{ }^{*}$ とすると，Fig. 5 から推察されるよらに， 電位による割れ形態の变化を Fig. 10 のよらに分類する ことができる。すなるか， $\mathrm{V}_{\mathrm{c}}{ }^{\prime}$ 近傍 $\left(\mathrm{V}_{\mathrm{c}}{ }^{\prime}\right.$ に近い不働態 電位域も含わて) では (100) faceting 溶解による井戸型 の割れが， $\mathrm{V}_{\mathrm{c}}{ }^{\prime} \sim \mathrm{V}_{\mathrm{c}}{ }^{*}$ では食孔底に同様の割れが浔めら れる。しかし $\mathrm{V}_{\mathrm{e}}{ }^{*}$ 以上では食孔の成長速度が割れの成 長速度より大きくなり，食孔の成長による惩性破䘫 (MF) が起こるようになる。最近, 辻川ら ${ }^{16,1 \tau}$ は $\mathrm{H}_{2} \mathrm{SO}_{4}$ $+\mathrm{NaCl}$ 溶液中での 304 銅の SCC が食孔底にできた方 位性ピッ下㚾起点として起こること, さらに(100) faceting 溶解の重要性を指摘している。小若ら 20 も $\mathrm{MgCl}_{2}$ の温度と濃度を下げると，割れは食孔を経由し て発生すると述べている。このようなことから食孔と割 れ，またはき裂と faceting 溶解とはけっして独立に存在 するものではなく，相互に密接な関係をもって SCC に 関与しているもの之考光られる。

\section{4 純 Al $の$ SCC}

最近，純金属でも $\mathrm{SCC}$ を起こすという興味ある報告

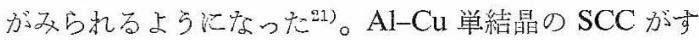
ベりステップの出現と，そこでの (100) faceting 溶解に よって起こるとすれば（Cu の役割は必ずしも明膫では ないが)，純 $\mathrm{Al} て ゙ る$ 本質的な違いはないはずである。 そこで純 $\mathrm{Al}$ 単結㫛について $1 \mathrm{~mol} / \mathrm{kg}-\mathrm{NaCl}$ 溶液中, 定電位下で SCC 試験党行った。その結果を Fig. 11 に 示した。破壊時間は $\mathrm{V}_{\mathrm{e}}{ }^{\prime}$ を越えると， $\mathrm{Al}-\mathrm{Cu}$ と同様に 電位の増加とともに指数関数的に減少した。Fig. 12 は $\mathrm{V}_{\mathrm{c}}{ }^{\prime}$ よりわずかた高い $\mathrm{E}=-0.75 \mathrm{~V}$ の定電位下で $\mathrm{SCC}$ 試験を行い，10 $10^{3} \mathrm{~min}$ 後に試験片を取りはずして表面を 観察したものである。Al-Cu 単結晶の $\mathrm{SCC}$ の特徴であ る(100) trace に沿った (100) faceting 溶解がこの場合 も認められ，試験をさらに継続すると，井戸型の割れへ と成長する。このよらな割れは $\mathrm{Al}-\mathrm{Cu}$ 合金と同様に， $\mathrm{V}_{\mathrm{c}}{ }^{\prime}$ に近い不働態電位域でも観察される。しかし $\mathrm{E}-$ $0.70 \mathrm{~V}$ になると Fig. 13 に示すように, 全面が (100) faceting 溶解を起こすようになる。すちろん，無応力下 でこの電位に保持すると，ごく普通の孔食を起こすのみ

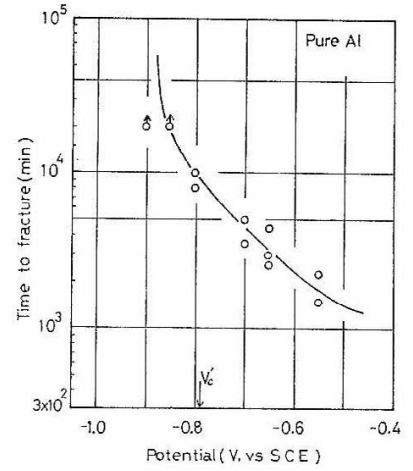

Fig. 11. Effect of applied potential on the time to fracture of pure $\mathrm{Al}$ in $1 \mathrm{~mol} / \mathrm{kg}-\mathrm{NaCl}$ solution.

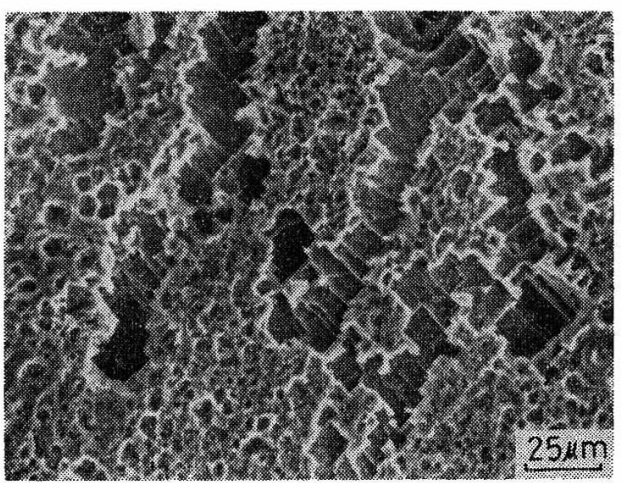

Fig. 12. (100) faceting dissolution along (100) traces of pure $\mathrm{Al}$ at $-0.75 \mathrm{~V}$ in $1 \mathrm{~mol} / \mathrm{kg}-$ $\mathrm{NaCl}$ solution.

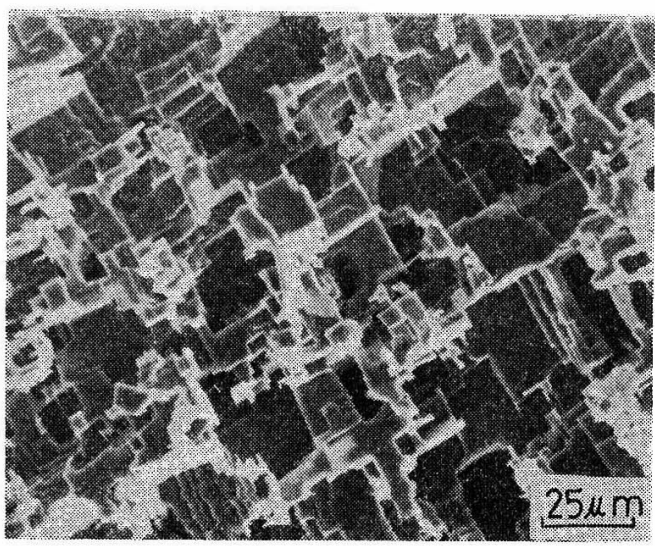

Fig. 13. (100) faceting dissolution of pure Al at $-0.70 \mathrm{~V}$ in $1 \mathrm{~mol} / \mathrm{kg}-\mathrm{NaCl}$ solution.

である。上述したように定電位保持る行えば，純 $\mathrm{Al}$ で も SCC 在起こすが，その電位域は $\mathrm{Al}-\mathrm{Cu}$ 合金に比べ て非常に狭く， $V_{\mathrm{e}}^{\prime}$ のごく近傍に限られる。

$3.5 \mathrm{NaCl}+\mathrm{H}_{2} \mathrm{O}_{2}$ 溶液中における $\mathrm{SCC}$ 試験の意味 $\mathrm{Al}$ 合金の $\mathrm{SCC}$ 試験液として $\mathrm{NaCl}+\mathrm{H}_{2} \mathrm{O}_{2}$ 系溶液が 
広く利用されている。そこでこの溶液中での $\mathrm{Al}-\mathrm{Cu}$ 合 金の SCC の電気化学的意味を知るために, まず $1 \mathrm{~mol} /$ $\mathrm{kg}-\mathrm{NaCl}+0.09 \mathrm{~mol} / \mathrm{kg}-\mathrm{H}_{2} \mathrm{O}_{2}$ 溶液中, 無応力下での自 然電極電位 $\left(\mathrm{E}_{\mathrm{corr}}\right)$ の経時変化を測定した。その結果を Fig. 14 に示した。図中の孔食電位 $\left(\mathrm{V}_{\mathrm{c}}{ }^{\prime}\right)$ と保護電位 $\left(E_{R}\right)$ はFig. 1 に示した $1 \mathrm{~mol} / \mathrm{kg}-\mathrm{NaCl}$ 溶液中に打将 る分極曲線から求めた值である。 $\mathrm{E}_{\text {corr }}$ は $\mathrm{Al}-1 \% \mathrm{Cu}$, $\mathrm{Al}-4 \% \mathrm{Cu}$ とも浸漬初期には $\mathrm{V}_{\mathrm{c}}{ }^{\prime}$ を越えているが，時 間の経過とともに低くなり，やがて一定值になる。しか しこの定常値は扮の抒のの合金の $\mathrm{E}_{\mathrm{R}}$ より高い電位にあ る。したがって Foroulis ${ }^{22,23)}$ が指摘しているように, この溶液中では一度 $\mathrm{V}_{\mathrm{e}}{ }^{\prime}$ を越えたことによって食孔が発 生し，乙か子定常値が $\mathrm{E}_{\mathrm{R}}$ より高いので，食孔はある程 度の活性を保って成長しらる条件にある。事実, 数 $\mathrm{h}$ 浸 漬した試料表面には多数の食孔が観察された。Fig. 15 は $1 \mathrm{~mol} / \mathrm{kg}-\mathrm{NaCl}+0.09 \mathrm{~mol} / \mathrm{kg}-\mathrm{H}_{2} \mathrm{O}_{2}$ 溶液中に試験片 を浸漬して $10 \mathrm{~min}$ 間保持した後，12\%/min の定ひず み速度で $1 \%$ の変形を与兄ては中断し, その間の $\mathrm{E}_{\text {corr }}$

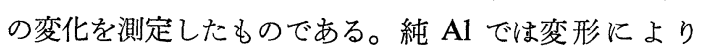
$\mathrm{E}_{\text {corr }}$ は $0.2 \mathrm{~V}$ 程度卑になるとともに, 繰返し変形する と全体として卑な值に移行する。それに対して, $\mathrm{Al}-\mathrm{Cu}$ 合金では変形による $\mathrm{E}_{\mathrm{corr}}$ の変化も約 $0.01 \mathrm{~V}$ と小さく,

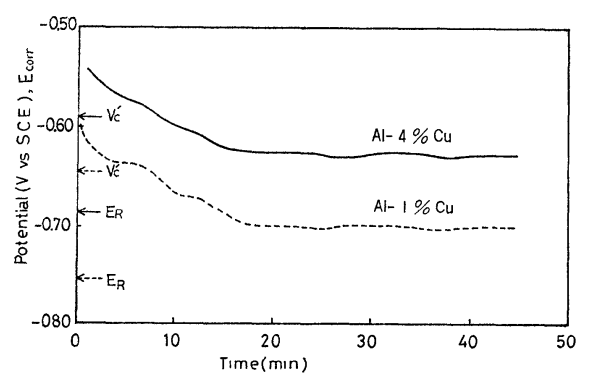

Fig. 14. Change of corrosion potentials with time in $1 \mathrm{~mol} / \mathrm{kg}-\mathrm{NaCl}+0.09 \mathrm{~mol} / \mathrm{kg}$ $\mathrm{H}_{2} \mathrm{O}_{2}$ solution.

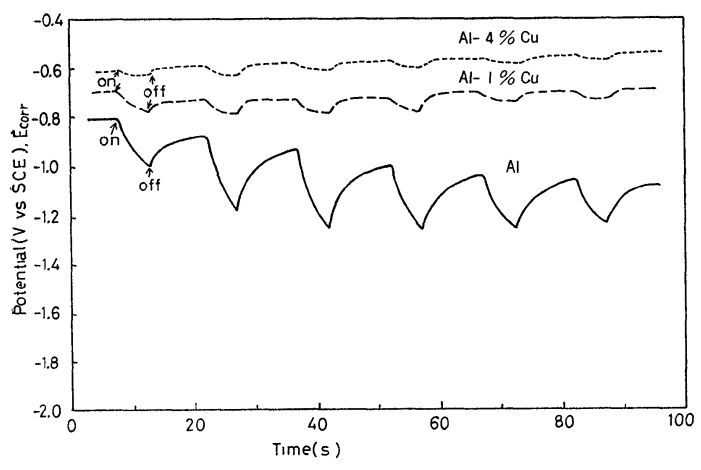

Fig. 15. Change of corrosion potentials by intermittent $1 \%$-straining in $1 \mathrm{~mol} / \mathrm{kg}$ $\mathrm{NaCl}+0.09 \mathrm{~mol} / \mathrm{kg} \mathrm{H}_{2} \mathrm{O}_{2}$ solution.

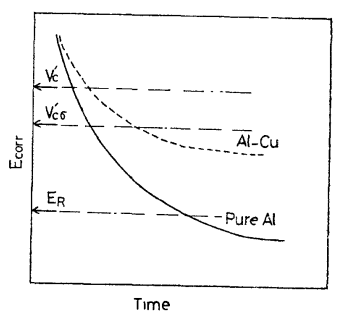

Fig. 16. Schematic representation of change of corrosion potentials with time for pure $\mathrm{Al}$ and $\mathrm{Al}-\mathrm{Cu}$ alloy.

繰り返し変形すると，全体として $\mathrm{E}_{\mathrm{corr}}$ はわずかに貴方 向に变化する。この理由は明らかではないが, 純 $\mathrm{Al}$ と $\mathrm{Al}-\mathrm{Cu}$ 合金の変形挙動 ${ }^{24}$ ) (応力ーひずみ曲線の形, すべ り線の分布抢よびすべりステップの高さなど）に関係す るようにも考学られる。変形下に执ける $\mathrm{E}_{\mathrm{R}}$ の測定は とくに行っていないが, Fig. 6, Fig. 14 および Fig. 15 なぞの結果を考え合わせると, $\mathrm{NaCl}+\mathrm{H}_{2} \mathrm{O}_{2}$ 溶液中にお ける SCCを Fig. 16 のように考えることができる。 $\mathrm{Al}-\mathrm{Cu}$ 合金では初期には $\mathrm{E}_{\mathrm{corr}}$ は $\mathrm{V}_{\mathrm{e} \sigma}{ }^{\prime}$ (SCC において は $\mathrm{V}_{\mathrm{c}}{ }^{\prime} よ り も \mathrm{~V}_{\mathrm{c} \sigma}{ }^{\prime}$ の方が重要な意味をるつであろう) 以上飞あるが，時間の経過とともに $\mathrm{V}_{\mathrm{e} o} \sigma^{\prime}$ と $\mathrm{E}_{\mathrm{R}}$ の間の 一定值になる。この電位では食孔自身の成長速度は遅 く, 割れは (100) faceting 溶解によって進行し, 井戸型 の割れとなる。しかし純 $\mathrm{Al}$ では $\mathrm{E}_{\mathrm{corr}}$ が時間の経過と ともに低くなり，Fig. 15 から予想されるように $\mathrm{E}_{\mathrm{R}}$ 以 下になる可能性がある。したがって，この場合には食孔 は再不働態化し, 割れの進行も停止するものと考兄られ る。

\section{4. まとめ}

純 $\mathrm{Al}$ 拈よび固溶体化した $\mathrm{Al}-\mathrm{Cu}$ 単結晶について $\mathrm{NaCl}$ 溶液中, 定電位下で応力腐食割れ試験を行い, 割 れの形態と電位の関係, faceting 溶解の役割, さらに $\mathrm{Al}$ 合金の割れ試験液として利用されている $\mathrm{NaCl}+\mathrm{H}_{2} \mathrm{O}_{2}$ 溶液の電気化学的意味などを孔食電位に注目しながら検 討した。その結果，次のような結論を得た。

(1) $1 \mathrm{~mol} / \mathrm{kg}-\mathrm{NaCl}$ 溶液中，定電位下の $\mathrm{SCC}$ 試験 では, $\mathrm{Al}-1 \% \mathrm{Cu}, \mathrm{Al}-4 \% \mathrm{Cu}$ いずれの合金でも孔食電 位 $\left(\mathrm{V}_{\mathrm{c}}{ }^{\prime}\right)$ 以上では, 破壊時間電位の增加とともに指数 関数的に減少した。

(2) 割れの形態は電位によって変化し, $\mathrm{V}_{\mathrm{c}}{ }^{\prime}$ 近傍 $\left(\mathrm{V}_{\mathrm{c}}{ }^{\prime}\right.$ に近い不働態電位域も含めて) では井戸型の割れ が，電位が高くなると食孔底に同様の割れが，さらに電 位が高くなると食孔のみとなる。したがって食孔のみが 観察される電位（約一 $0.4 \mathrm{~V}$ 以上）で起こる破壊は $\mathrm{SCC}$ ではなく，食孔の成長による延性破壊である。 
（3）純 $\mathrm{Al}$ でも $\mathrm{V}_{\mathrm{c}}^{\prime}$ 近傍では $\mathrm{Al}-\mathrm{Cu}$ 合金と同様に 井戸型の SCC を起こすが，その電位幅はきわめて狭 w。

（4）純 $\mathrm{Al}$ 括よび $\mathrm{Al}-\mathrm{Cu}$ 合金のいずれに括いても, SCC を起こす電位の下限は応力下に特ける孔食電位 $\left(\mathrm{V}_{\mathrm{c} \sigma}{ }^{\prime}\right)$ と考光られる。

(5) SCC はいずれの 合金でも割れ先端での ( 100) faceting 溶解によって進行し，側壁は常に (100) からな る。

(6) $1 \mathrm{~mol} / \mathrm{kg}-\mathrm{NaCl}+0.09 \mathrm{~mol} / \mathrm{kg}-\mathrm{H}_{2} \mathrm{O}_{2}$ 溶液中で の自然電極電位 $\left(\mathrm{E}_{\mathrm{corr}}\right)$ は浸漬初期には $\mathrm{V}_{\mathrm{c} \sigma}{ }^{\prime}$ を越えてい るが，時間の経過とともに一定值となる。この定常值は おのおのの合金の保護電位 $\left(\mathrm{E}_{\mathrm{R}}\right)$ より高いため，食孔は ある程度の活性を保って成長し， SCC を起こす。しか し純 $\mathrm{Al}$ では変形が進むにつれて $\mathrm{E}_{\mathrm{corr}}$ は $\mathrm{E}_{\mathrm{R}}$ 以下にな るので, 食孔は再不働態化し, 割れの進行も停止する。

本研究の一部は昭和 51 年度文部省科学研究費 (一般 研究 (D)) の援助によって行われた。ここに深く感謝の 意を表する次第である。

(Received June 6, 1977)

\section{文献}

1) W. W. Kirk, F. H. Beck and M. G. Fontana: Physical Metallurgy of Stress Corrosion Fracture, p.227, AIME (1959).

2）伊藤伍郎, 石原只雄, 清水義彦：金属 学会誌, 30, 888 (1966).

3) 森田 茂：金属学会誌，25, 667 (1961).

4) J. R. Galvele and S. M. de DeMicheli: Corrosion Sci. 10, 795 (1970).
5）星野晃三，影山政夫，杉本克久，影山秀一，沢 田可信：金属学会誌, 39, 520 (1975).

6) J. C. Scully: The Theory of Stress Corrosion Cracking in Alloys, p. 223, NATO Sci. Affairs Div. (1971).

7) 小島 陽, 高橋恒夫：軽金属, 25, 64 (1975).

8) P. J. E. Forsyth: Acta. Met., 11, 703 (1963).

9) R. M. N. Pelloux: Trans. AIME, 62, 282 (1969).

10）小島 陽，高橋恒夫：軽金属，25, 64 (1975).

11) C. A. Stubbington: Metallurgia, 68, 109 (1963).

12) A. R. C. Westwood and M. H. Kamder: Trans. ASM, 60, 723 (1967).

13) R. J. H. Wanhill: Corrosion, 30, 371 (1974).

14) C. Edeleanu: J. Inst. Metals, 89, 90 (1960).

15) J. R. Galvele, S. M. de DeMicheli, I. L. Muller, S. B. de Wexler and I. L. Alanis: U. R. Evans Intern. Conf. on Localized Corrosion, p. 580 (1971).

16）过川茂男，久松敬弘：第 23 回腐食防食討論会子 稿集, p. 17, (1976).

17）辻川茂男，久松敬弘：腐食防食協会 春期学術講 演大会予稿集, p . 118, (1977).

18）昆 謙造, 佐藤昭規, 大谷南海男: 防食技術, 25, 589 (1976).

19) R. W. Staehle: Intern. Conf. on Stress Corrosion Cracking and Hydrogen Embrittlement of Iron Base Alloys, Unieux-Firminy (1973).

20) 小若正倫，工藤赴夫：鉄と鋼，62, 390 (1976).

21）鈴木揚之助，久松敬弘：防食技術，23，29, 477 (1974).

22) Z. A. Foroulis: Proc. 5th Intern. Cong. on Metallic Corrosion, p. 326 (1975).

23) Z. A. Foroulis and M. J. Thubrikar: Electrochim. Acta, 21, 225 (1976).

24）昆 謙造，大谷南海男：金属学会誌，37，289 (1973). 